\title{
左側下大静脈を伴った腹部大動脈瘤の 1 手術例
}

\author{
服 部 隆司渡辺泰徳金本真也
}

\begin{abstract}
比較的まれな静脈奇形である左側下大静脈を伴った腎動脈下腹部大動脈瘤の 1 例を報告した。症例は 72 歳, 男性. 下大静脈は腎動脈分岐直下の腹部大動脈の前面を横切って左側に移行していた。 下大 静脈に taping をして頭側に牽引しながら大動脈を遮断, 中枢側吻合を行った. 術中血圧等の変動は なく, Y 型人工血管置換術を行い, 術後の経過も順調であった. 日心外会誌 26 巻 3 号 : 204-206 (1997)
\end{abstract}

Keywords：左側下大静脈，腹部大動脈瘤

\begin{abstract}
A Case Report of Abdominal Aortic Aneurysm with Isolated Left-side Inferior Vena Cava Takashi Hattori, Yasunori Watanabe and Shinya Kanemoto (Department of Cardiovascular Surgery, Hitachi General Hospital, Hitachi, Japan)

Isolated left-side inferior vena cava is rare, there being only four cases associated with abdominal aortic aneurysm reported so far in the Japanese literature. A 72-year-old man was admitted to our hospital for the evaluation of an abdominal pulsatile mass. CT scan revealed abdominal aortic aneurysm with isolated left-sided inferior vena cava. Aneurysmectomy and bifurcated graft replacement was performed with retracting inferior vena cava. The postoperative course was uneventful. Jpn. J. Cardiovasc. Surg. 26: 204-206 (1997)
\end{abstract}

左側下大静脈は比較的まれで，その発生頻度は $0.2 \sim 0.5 \%$ といわれているが，これ自体病的意義 は少ない.しかし腹部大動脈瘤のように下大静脈 と解剖学的に密接に関係する疾患と合併した場 合，手術操作に多少の工夫が必要となることもあ る. 今回左側下大静脈を合併した腹部大動脈瘤の 手術例を経験したので若干の文献的考察を加えて 報告する。

\section{症例}

症例：72 歳, 男性.

主訴：腹部拍動性腫瘤.

既往歴：1988 年, 急性心筋梗塞.

現症歴：高血圧，陳旧性心筋梗塞にて近医通院 中, 腹部拍動性腫瘤を指摘された。精査目的に本 院紹介となった。

入院時現症：身長 $162 \mathrm{~cm}$, 体重 $65 \mathrm{~kg}$, 血圧 $126 / 77 \mathrm{mmHg}$, 脈拍 $60 / \mathrm{min}$ 整, 心肺聴診上異 常を認めなかった．腹部触診では臍を中心に約 6 $\mathrm{cm}$ の拍動性腫瘤を触知し, 同部位から左鼠踩部

1996 年 10 月 18 日受付, 1996 年 11 月 27 日採用

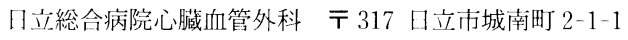

にかけて血管性雑音を聴収した。大腿動脈以下の 脈拍は左右差なく良好に触知した。

検査所見：血液一般，血液生化学，凝固系，尿 検査等では異常所見を認めなかった，胸腹部単純 $\mathrm{X}$ 線写真でも異常所見はなかった。腹部 CT scan では腎動脈下の大動脈から両側総腸骨動脈 に及ぶ最大径 $6.2 \mathrm{~cm}$ の壁在血栓を伴う動脈瘤 と，腎動脈分岐部から動脈瘤頸部にかけてその前 面を右から左に斜走し，その遠位側で動脈瘤の左 側に位置する下大静脈を認めた（図 1).大動脈 造影では腎動脈分岐下約 $2.5 \mathrm{~cm}$ のところから総 腸骨動脈にかけて動脈壁の不整と拡張を認めた (図 2).

以上より左側下大静脈を伴う腎動脈下腹部大動 脈瘤と診断し，1995 年 10 月 16 日手術を行った。

手術所見：腹部正中切開にて開腹した。後腹膜 は白く肥厚し動脈瘤と強く癒着していた，後腹膜 を頭側に切開すると腎動脈分岐直下の大動脈から 瘤頸部の前方を右から左に斜走する下大静脈を認 めた（図 3)。左総腸骨動脈の背側で左右の総腸 骨静脈が合流していた。大動脈前面を横切る下大 静脈を慎重かつ十分に剥離し tapingした。これ 


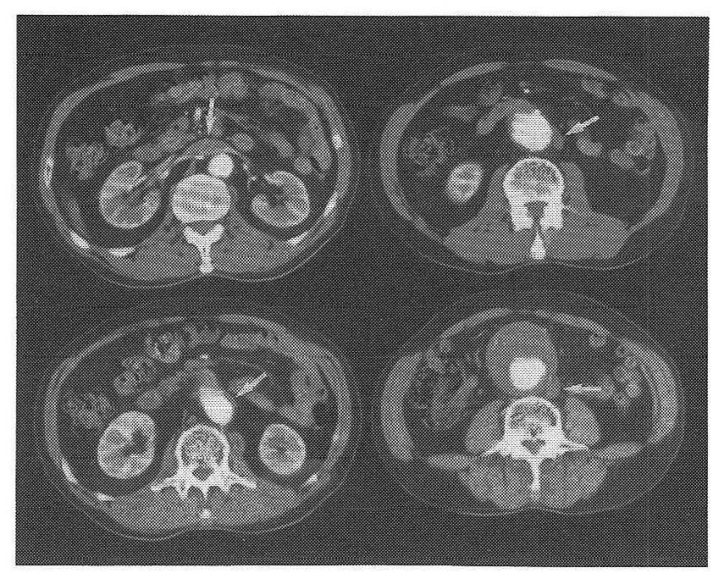

図 1 腹部 CT scan

下大静脈（矢印）が大動脈瘤上を左方に横切ってい る。

を頭側に牽引しながら腎動脈下の大動脈を遮断 し， $18 \times 9 \mathrm{~mm}$ の Y 型人工血管を用い intraluminal 法にて置換術を行った。術中血圧の 変動もなく順調に経過した。術後血管造影（図 4）は問題なく，術後 25 日目に退院した。

\section{考察}

下大静脈は発生学的に postrenal segment, renal segment, prerenal segment, hepatic segment の 4 部門から成る。左側下大静脈はそのう $ち$ postrenal segment $の$ left supracardial vein の遺残により発生するものが多い1が，その発生 頻度は $0.2 \sim 0.5 \%$ といわれ2)比較的まれな静脈 奇形である。

左側下大静脈自体は通常無症状で臨床的意義は 少ないが，腹部大動脈疾患や腎臓など後腹膜臓器 の手術ではその解剖学的位置関係が重要になる。 腹部大動脈溜と合併した場合，（1）左側下大静 脈は左後方に圧排され癒着や変位などで静脈壁が 脆弱化している3．（2）瘤が左側に破裂しやす いため動静脈㾇を形成しやすい4)。（3 ) 中枢側吻 合部の前面を下大静脈が横切るなどの問題が生じ $ろ^{3,5)}$. 術前画像診断で正確な解剖学的位置関係 を認識することにより，下大静脈損傷をさけるよ うにしなければならない。とくに破裂性腹部大動 脈瘤と合併したときには術前診断の重要性はさら に増すと思われる。中枢側吻合に関しては下大静

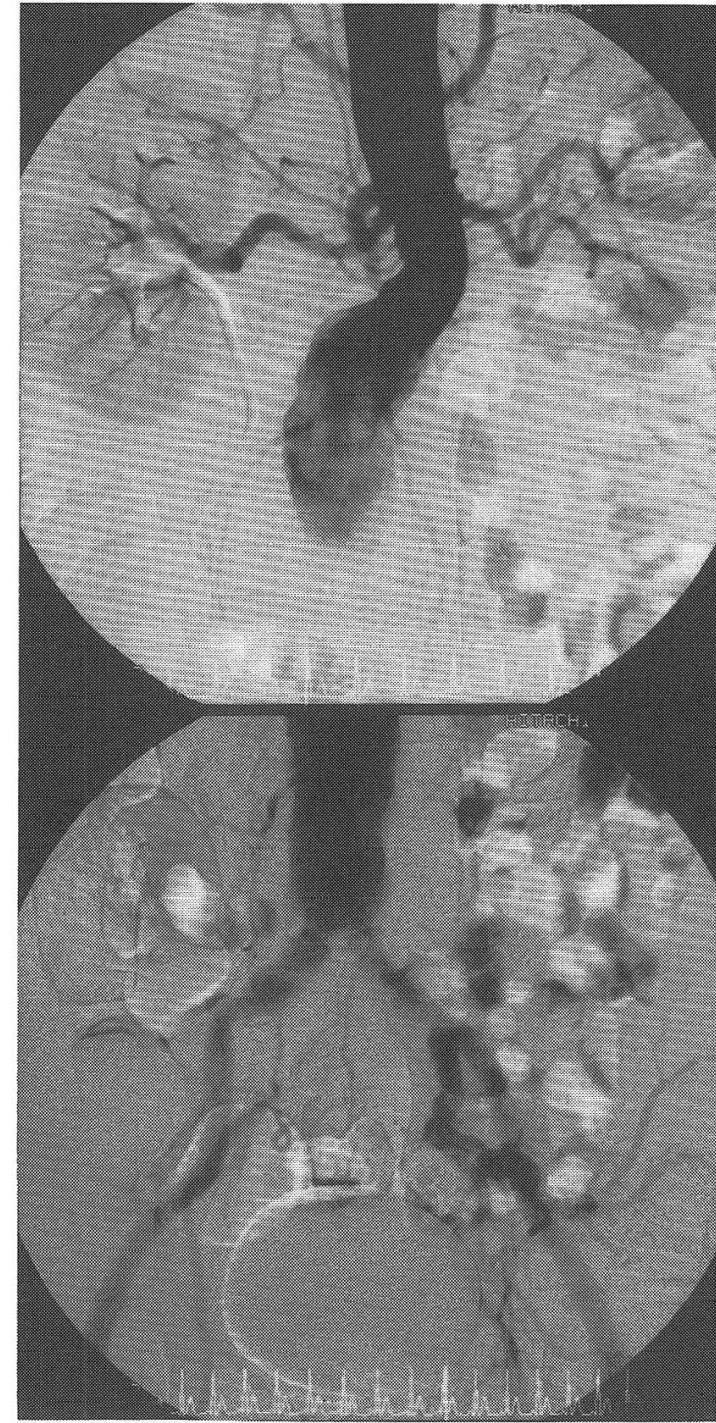

図 2 大動脈造影

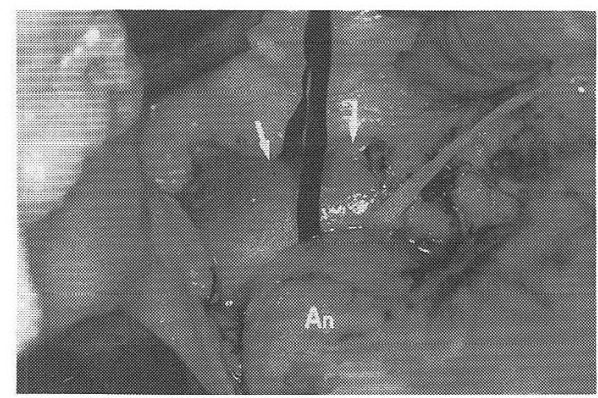

図 3 術中所見

下大静脈（矢印）が大動脈瘤（An）上を左方に横切 っている。 


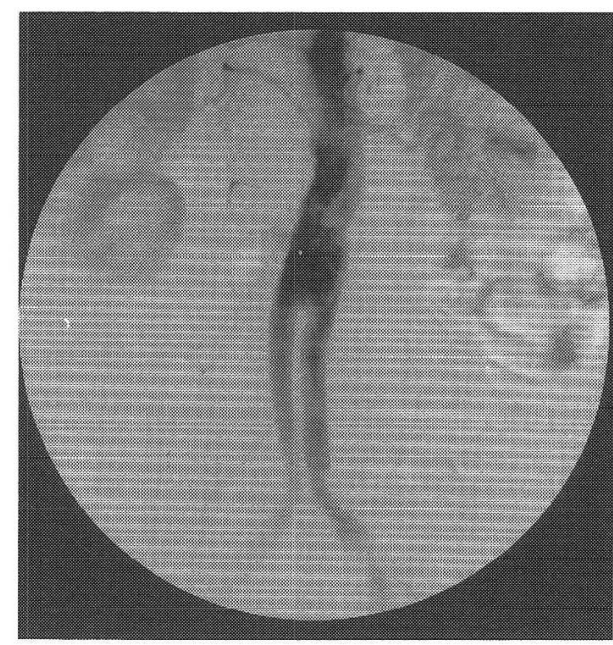

図 4 術後造影

脈を一時的に切断したとの報告6)もあるが，本症 例のように下大静脈を慎重かつ十分に剝離し taping を行い, 牽引することで大動脈遮断や中枢側 吻合は十分可能であると思われた。左側下大静脈 と腹部大動脈瘤の合併例の報告は少なく, 本邦で は文献上 4 例 6 -9) のみで自験例が 5 例目の報告で ある。

\section{文献}

1) Chuang, V. P., Mena, C. E. and Hoskins, P. A. :
Congenital anomalies of the inferior vena cava. Review of embryogenesis and presentation of a simplified classification. Brit. J. Radiol. 47: 206-213, 1974.

2) Sarma, K. P.: Anomalous inferior vena cavaAnatomical and clinical. Brit. J. Surg. 53: 600602, 1966.

3) Dupont, J.: Isolated left-sided vena cava and abdominal aortic aneurysm. Arch. Surg. 102: 211-212, 1971.

4) Davichi, A. A., Thomas, J. Dale, W. A. et al. : Acute spontaneous rupture of an arteriosclerotic aneurysm into isolated left-sided inferior vena cava. Am. J. Cardiol. 15 : 416-418, 1965.

5) Bartle, E. J., Pearce, W. H., Sun, J. H. et al. : Inferior venous anomalies and aortic surgery: Avoiding vascular injury. J. Vasc. Surg. 6: 590593, 1987.

6）増田政久, 高原善治, 武内重康ほか：左側下大静 脈を伴った腎動脈下腹部大動脈瘤の 1 手術例. 日 血外会誌 2: 509-513, 1993.

7）榊原成純, 村田繁利, 竹中正治ほか：左側下大静 脈と腹部大動脈溜が併存した1例. 臨放 $32 ： 865^{-}$ 868, 1987.

8）石部良平, 丸古臣崮, 有川和厷ほか：左側下大静 脈を伴った腹部大動脈瘤の 1 手術例. 日外会誌 91: 782-784, 1991.

9）日置正文, 武井 裕, 増田 栄ほか: 左側下大静 脈を伴った破裂性腹部大動脈瘤の一治験例. 日外 会誌 92: 1524-1527, 1991. 